\title{
Effects of Varieties and Population of Soybean Intercropped with Maize on Yield and Yield Components of Associated Crops
}

\author{
Negasa Dangia ${ }^{1}$, Zerihun Jalata $^{2, *}$, Gerba Daba $^{3}$ \\ ${ }^{1}$ Oromia Agricultural Office, Wama-Hagelo District Office, Wama Hagalo, Ethiopia \\ ${ }^{2}$ Department of Plant Sciences, Faculty of Agriculture, Wollega University, Nekemte, Ethiopia \\ ${ }^{3}$ Department of Horticulture and Plant Science, College of Agriculture and Veterinary Medicine, Jimma University, Jimma, Ethiopia \\ Email address: \\ dangianagasa@gmail.com (N. Dangia),jaluu_z@yahoo.com (Z. Jalata), gerbadaba8@gmail.com (G. Daba) \\ ${ }^{*}$ Corresponding author
}

\section{To cite this article:}

Negasa Dangia, Zerihun Jalata, Gerba Daba. Effects of Varieties and Population of Soybean Intercropped with Maize on Yield and Yield Components of Associated Crops. Journal of Plant Sciences. Vol. 9, No. 4, 2021, pp. 128-138. doi: 10.11648/j.jps.20210904.12

Received: August 19, 2020; Accepted: September7, 2020; Published: July 15, 2021

\begin{abstract}
Cereal-legume intercropping practices improve the sustainability of production and productivity. However, identification of suitable crop and plant density of the component crops is essential. A field experiment was conducted to evaluate the varietal effects of soybean intercropped with maize and the effect of plant densities of soybean varieties intercropped with maize on yield and yield components of associated crops and the productivity of the system at WamaHagelo District, western Ethiopia during 2019. Maize variety 'P1238W' (Limu) was intercropped with three varieties of soybean ('Jalale,' 'Boshe' and local) in a factorial combination of three populations densities of $25 \%, 50 \%$, and $75 \%$ of the recommended population density along with the sole crops of the irrespective varieties of soybean and maize in randomized complete block (RCB) design with three replications. Data was collected on growth, yield and yield related parameters on both crops. The result revealed a plant density of intercropped soybean varieties significantly $(\mathrm{P}<0.01)$ affected yield and yield components of maize. Highest values for the number of ears per plant (1.88) and grain yield $\left(7.19 \mathrm{tha}^{-1}\right)$ of maize were obtained from $25 \%$ soybean population and particularly from variety 'Boshe' for grain yield. Moreover, plant population and soybean variety significantly $(\mathrm{P}<0.01)$ affected grain yield of soybean showing the highest grain yield $\left(1.58 \mathrm{tha}^{-1}\right)$ of soybean was recorded for variety 'Boshe'. Generally, the highest LER (Land equivalent ratio) of grain yield (1.65 tha ${ }^{-1}$ ) and highest net benefit (44491.40 ETB (Ethiopian Birr) or 1334.7USD ha ${ }^{-1}$ ) obtained from maize intercropped with 'Boshe' variety at a population of $50 \%$ revealing intercropping maize with 'Boshe' soybean at 50\% plant population found to be appropriate to achieve high productivity.
\end{abstract}

Keywords: Cropping System, Crop Productivity, Intercropping, Maize, Soybean, Yield

\section{Introduction}

Low crop productivity and rapid population growth is the main problem facing sub-Saharan Africa including Ethiopia. To feed the ever-increasing human population and accomplish the increasing demand for agricultural products, agricultural production and productivity must be increased beyond the current level [1]. Therefore, to enhance and sustain agricultural productivity with minimum degradation of natural resources, the efficient use of available growth resources is imperative. Hence, in order to ensure both food security and environmental quality, it is essential to seek best management practices, which include appropriate cropping systems that can efficiently utilize solar and soil resources with minimum nutrient inputs [2, 3].

Intercropping is the agricultural practice of cultivating two or more crops in the same space at the same time [4]. Intercropping is a common practice in many areas of Africa as a part of traditional farming systems commonly implemented due to declining land sizes and food security problems $[5,6]$. It is also considered as a means to address some of the major problems associated with modern 
farming including moderate yield, pest and pathogen accumulation, soil degradation and environmental deterioration, thereby helping to deliver sustainable and productive agriculture $[4,7]$. Intercropping is an example of sustainable agricultural systems that contribute to achieving ecological balance, more utilization of available growth resources such as nutrients, water and light, and a way to increase diversity in the agricultural ecosystem [8, 9]. According to Seran and Brintha [10] intercropping systems control soil erosion by preventing raindrops from hitting the bare soil, offers greater financial stability than sole cropping. That means intercropping allows high insurance against crop failure, notably in environments known for heavy weather conditions like frost, flood, drought, and overall provides high financial stability for farmers [4].

Maize based intercropping system with legume helps in improving soil health as well as the yield of the crop [11] but competition among mixtures and population densities of the component crops in cereal legume intercropping is the major aspect affecting yield as compared with sole cropping of cereals [12]. On the other hand, soybean is the primary source of edible oil globally with the highest gross output of vegetable oil $(20 \%)$ and protein $(40 \%)$ which can substitute other pulse crops and animal products such as meat and milk [13]. Though soybean is recently introduced in Ethiopia, soybean has grown very fast with a national average yield of 2.1 tha $^{-1}$. Its productivity depends on varietal selection, population density including when grown as intercrop. Comparative analyses of various crops intercropped with soybean have indicated that maize is the best partner in a soybean intercropping system [14].

In Ethiopia, maize is one of the most important major food crops among cereal, ranking second after teff in area coverage and first in production and productivity with a national average yield of 3.7 ton $\mathrm{ha}^{-1}$ [13]. Economically viable intercropping largely depends on adaptation of intercrop pattern and selection of compatible crops that maximize positive interaction and minimize competition [15]. One of the key factors successful for intercropping is proper plant density, which depends on the plant species as well as the particular varieties used [16]. However, currently in southwestern Ethiopia, sole cropping of the maize crop is widely practiced though there is a shortage of arable land and greater benefits of intercropping maize with legumes, particularly with soybean [17]. Therefore, to utilize the resources efficiently and improve productivity, the information on maize-soybean intercropping as well as, varietal selection and planting density with intercropping is an important knowledge gap that requires investigation in the study area. Thus, this study was designed with the objectives of determining the varietal effects of soybean (Glycine max L.) intercropped with maize (Zea mays L.) and the effect of plant densities of soybean varieties intercropped with maize on yield and yield components of associated crops and the productivity of the system.

\section{Materials and Methods}

\subsection{Study Area}

Field experiment was conducted during 2019 main cropping season under the rainfed condition at Wama Hagelo District, Bata Kusaye Farmers Training Center (FTC), located in Oromia Regional State, in East Wollega Zone, West Ethiopia at a distance of $322 \mathrm{~km}$ from Addis Ababa. The site is located at latitude of $8^{\circ} 55^{\prime} 7^{\prime \prime} \mathrm{N}$ and $36^{\circ} 55^{\prime} 55^{\prime \prime} \mathrm{E}$, with an elevation of 1609 meters above sea level. It has a warm humid climate with an average minimum and maximum temperature of 18 and $27^{\circ} \mathrm{C}$, respectively, and receives an average annual rainfall of $1500 \mathrm{~mm}-2200 \mathrm{~mm}$ which covers from April to October. The soil type of the experimental site was reddish-brown and its $\mathrm{pH}$ is 5.82. The area was characterized by maize dominant based farming system and crop-livestock mixed farming system in which cultivation of maize, sorghum, and niger seed are the major crops grown in the area (Wama-Hagelo District Agriculture and Natural Resource Office, 2019 unpublished).

\subsection{Description of Experimental Materials}

Improved maize variety ('P 3812 W') was used as the main crop which is adapted to the area and high yielding and more preferred by farmers of this area. And three soybean varieties namely 'Boshe', 'Jalale' (introduced from Bako Agricultural Research Center), and local (obtained from Bata-Kusaye FTC) were used similarly with high yield potential and adapted to an altitude of 1200-1900 m above sea level [18]. Thus, the experiment consisted of two factors namely soybean varieties ('Jalale', 'Boshe', and local variety) and plant populations $(25 \%, 50 \%$, and $75 \%$ of the sole population of each variety, which is 250,000 plants ha ${ }^{-1}$ ) and each soybean variety was intercropped with maize.

\subsection{Experimental Design, Treatments and Layout}

The treatment consisted of planting of maize at density of $100 \%$ of sole crop with three common bean varieties ('Jalale','Boshe' and local variety) at the density of $25 \%$ (62,500 plants ha-1), 50\% (125,000 plants ha-1) and75\% (187,500 plantsha-1).

The plot of both sole and intercropped maize and soybean had a size of $4.2 \mathrm{~m} * 6 \mathrm{~m}=25.2 \mathrm{~m}^{2}$. Generally, the total plot of the experiment had a size of $66.6 \mathrm{~m} * 21 \mathrm{~m}=1398.6 \mathrm{~m}^{2}$. The soybean varieties were sown in between rows of maize with a spacing of $37.5 \mathrm{~cm}$ far from each maize row, by maintaining 5,10 , and $15 \mathrm{~cm}$ intra row spacing for $75 \%, 50 \%$, and $25 \%$, respectively. The intra-row spacing for soybean varieties was adjusted according to planting density in the system. Hence, the soybean population $\mathrm{ha}^{-1}$ used in the intercrop for $75 \%, 50 \%$ and $25 \%$ was $187,500,125,000$ and 62,500 plants, respectively. Sole maize and soybean were planted at their optimum plant densities of 44,444 and 250,000 plants $\mathrm{ha}^{-1}$, respectively. Sole maize was planted in a row of $75 \mathrm{~cm} \mathrm{x} 30 \mathrm{~cm}$ and sole soybean was planted by maintaining $40 \mathrm{~cm}$ and $10 \mathrm{~cm}$ inter and intra row spacing, 
respectively. There were nine rows of maize in each plot; each row had a length of $4.2 \mathrm{~m}$ and a width of $6 \mathrm{~m}$. The middle seven rows were used for data collection. The spacing between adjacent replication was $1.5 \mathrm{~m}$ and that of the adjacent plot was $1 \mathrm{~m}$. The experiment was laid out in RCB design a factorial arrangement of two factors of soybean varieties and plant populations with three replications. The experiment consisted of two factors namely soybean varieties and plant populations. Each soybean variety was intercropped with maize. The experiment consisted of 13 treatments and 39 plots. Each treatment was randomly assigned to the experimental unit within a block. The three soybean varieties were intercropped with maize in the combination as shown in Table 1.

Table 1. Treatment combinations.

\begin{tabular}{llll}
\hline No. & Treatment combination & Description & Plant populations \\
\hline 1 & $100 \mathrm{M}, 25 \mathrm{~B}$ & $100 \%$ maize $+25 \%$ Boshe $(62,500)$ & 62,500 \\
2 & $100 \mathrm{M}, 50 \mathrm{~B}$ & $100 \%$ maize $+50 \%$ Boshe $(125,000)$ & 125,000 \\
3 & $100 \mathrm{M}, 75 \mathrm{~B}$ & $100 \%$ maize $+75 \%$ Boshe $(187,500)$ & 187,500 \\
4 & $100 \mathrm{M}, 25 \mathrm{~J}$ & $100 \%$ maize $+25 \%$ Jalale $(62,500)$ & 62,500 \\
5 & $100 \mathrm{M}, 50 \mathrm{~J}$ & $100 \%$ maize $+50 \%$ Jalale $(125,000)$ & 125,000 \\
6 & $100 \mathrm{M}, 75 \mathrm{~J}$ & $100 \%$ maize $+75 \%$ Jalale $(187,500)$ & 187,500 \\
7 & $100 \mathrm{M}, 25 \mathrm{~L}$ & $100 \%$ maize $+25 \%$ Local $(62,500)$ & 62,500 \\
8 & $100 \mathrm{M}, 50 \mathrm{~L}$ & $100 \%$ maize $+50 \%$ Local $(125,000)$ & 125,000 \\
9 & $100 \mathrm{M}, 75 \mathrm{~L}$ & $100 \%$ maize $+75 \%$ Local $(187,500)$ & 187,500 \\
10 & $0 \mathrm{M}, 100 \mathrm{~B}$ & Sole Boshe & 250,000 \\
11 & $0 \mathrm{M}, 100 \mathrm{~J}$ & Sole Jalale & 250,000 \\
12 & $0 \mathrm{M}, 100 \mathrm{~L}$ & Sole Local & 250,000 \\
13 & $100 \mathrm{M}$ & Sole maize & 44,444 \\
\hline
\end{tabular}

$\mathrm{M}=$ Maize, $\mathrm{B}={ }^{\prime}$ Boshe' soybean variety, $\mathrm{J}={ }^{\prime} J a l a l e '$ soybean Variety and $\mathrm{L}=$ Local variety of soybean, Total plot area $=66.6 \mathrm{~m} * 21 \mathrm{~m}=1398.6 \mathrm{~m}^{2}$

\subsection{Experimental Procedure and Field Management}

In order to achieve better seedling establishment, the land was plowed and leveled before planting using local oxen plough. Two seeds were planted per hill and later on seedlings were thinned to one plant per hill two weeks after emergence and soybean varieties were sown at 15 days during maize thinning. At time of planting both sole and intercropped maize received $100 \mathrm{~kg} \mathrm{ha}^{-1}$ of NPS (19N$38 \mathrm{P}_{2} \mathrm{O}_{5^{-}}-7 \mathrm{SO}_{4}$ ) and $75 \mathrm{~kg} \mathrm{ha}^{-1}$ of Urea was applied uniformly into all plots. All the NPS were applied at planting, while urea $\left(150 \mathrm{~kg} \mathrm{ha}^{-1}\right)$ was applied in two splits $\left(75 \mathrm{~kg} \mathrm{ha}^{-1}\right)$ at planting and the remaining half $\left(75 \mathrm{~kg} \mathrm{ha}^{-1}\right)$ at 40 days after sowing). For sole soybeans, $100 \mathrm{DAP} \mathrm{kg} \mathrm{ha}^{-1}$ was applied at the time of sowing. Urea $(\mathrm{N})$ was not applied into sole soybean assuming the soybean could benefit from self-fixed nitrogen. All cultural practices were applied in accordance to the recommendation. Both maize and soybean were harvested from the net plot after they attained their normal physiological maturity and they were threshed manually.

\subsection{Data Collection Procedures}

\subsubsection{Maize Components}

Phenological and growth parameters of Maize: Data on days to $50 \%$ tasselling for maize was taken on the number of days from planting to $50 \%$ of the plants produced tassel and/or silk. Days to $90 \%$ physiological maturity was recorded when $90 \%$ of the plants reached black layer formation stage [19]. Plant height for maize was measured at silking stage from five randomly taken plants per net plot and the average was taken for analysis. Leaf length was measured from the ligule to apex for all five randomly selected plants after anthesis and the average was recorded for the plot. Leaf width was measured at the widest point along its length for all five randomly selected plants after anthesis and the average was recorded for the plot. Leaf area of five randomly taken plants from net plot area was determined at $50 \%$ of tasseling stage using the method described by Sticker et al. $[20]$ as leaf area=leaf length $x$ maximum width of leaf $x 0.75$. Leaf area index was calculated by dividing the leaf area of five plants to the ground area occupied by the plant [19].

Yield and Yield Related characters of Maize: The ear length of ten randomly selected plants were measured using a ruler after harvest and the average was recorded for the plot. Ear diameter of ten randomly selected plants was measured using ruler after harvest and the average was recorded for the plot [19]. Hundred kernel weights were determined by counting the number of kernels from a bulk of shelled seed and weighing it using sensitive balance from a plot at harvest after adjusting to $12.5 \%$ moisture content. Grain yield was determined for the net plot after shelling and the moisture content was adjusted to $12.5 \%$. Above-ground dry biomass was taken after sun drying for 20 days samples of plants from net plot [21]. Harvest index was calculated as the ratio of grain yield to the weight of above-ground dry biomass.

\subsubsection{Soybean Components}

Phenological and growth Parameters of Soybean: Days to $50 \%$ flowering and days to $90 \%$ physiological maturity was determined as the number of days from sowing to the time when $50 \%$ of the plants started to flowering and $90 \%$ physiological maturity based on visual observation. The number of primary branches were determined by counting the total number of primary branches from ten randomly taken plants at physiological maturity and measured from the ground level to the tip of the main stem by linear meter.

Yield and Yield Related Parameters of Soybean: Number of pods per plant was recorded by visual counting the pods of 
ten randomly selected soybeans in each net plot. And the number of seeds per pod was recorded by visual counting the seeds of ten randomly taken pods in each net plot at maturity and the final stand count was expressed in percent of the initial count to determine the loss in stand count due to competition. Above-ground dry biomass of the ten randomly taken plants were measured after sun drying at physiological maturity. Seed yield was recorded from the net plot area of each plot after sun drying for 10 days to the designated moisture content of $10 \%$ [22]. The weight (g) of 100 seeds were taken from seeds of each net plot at a moisture content of $10 \%$ and harvest index was also calculated.

System productivity: The system productivity of component crops were determined in terms of land equivalent ratio (LER) and Monetary advantage (MA). LER is defined as the relative land area required as a sole crop to produce the same yields as intercropping [23]. The LER from the yield of maize and soybean crop would be used to evaluate the productivity of intercropping versus sole cropping. Land Equivalent Ratio (LER) is the most common index adopted in intercropping to measure land productivity. LER was computed as follows:

$$
\begin{aligned}
& \mathrm{LER}=\frac{\text { Intercropped yield of maize }}{\text { Sole yield of maize }}+\frac{\text { Intercropped yield of soybean }}{\text { Sole Yield of Soybean }} \\
& \mathrm{MA}=\text { Values of combinedintercropped yield } \times \frac{\text { LER }-1}{\text { LER }}
\end{aligned}
$$

Monetary advantage (MA) was calculated from the yield of maize and soybean to measure the productivity and profitability of intercropping as compared to sole cropping of the associated component crops [23]. Monetary returns values were estimated based on the market price of produce (maize and soybean) during the harvest period. Accordingly, MV was calculated by multiplying yields of the component crops by their respective current market price for all varieties of soybean and maize yield. MA was calculated as described by Willey [24].

Soil Sampling and Analysis: Representative soil samples at a depth of $0-30 \mathrm{~cm}$ were taken randomly both before planting and after harvesting to determine some selected soil physicochemical properties. The samples were taken randomly in a zigzag pattern from 12 points across the experimental field and from the whole plots before planting and after harvesting respectively. The soil samples were air dried and ground to pass through $2 \mathrm{~mm}$ mesh size sieve. The composite soil samples were analyzed at Nekemte Soil Research Center for determination of Soil $\mathrm{pH}$, soil texture, total nitrogen, Cat ion Exchange Capacity (CEC), and soil organic matter.

\subsection{Statistical Analysis}

The analysis of variance (ANOVA) was carried out using statistical packages and procedures out lined by Gomez and Gomez [25]. Mean separations were carried out using the Least Significant Difference (LSD) at 5\% probability level.

\section{Results and Discussion}

\subsection{Physicochemical Properties of the Soil}

The soil texture of the experimental site was sandy clay soil with a proportion of $48 \%$ sand, $36 \%$ clay and $16 \%$ silt (Table 2) showing the textural class of the experimental soil was ideal for maize production [26]. The soil $\mathrm{pH}$ of the experimental site was 5.57 which is moderately acidic. The analytical results indicated that the organic carbon content of the experimental soil $(2.27 \%)$ is low according to Landon [27], who classified the organic carbon content of soil $<4 \%$, $4-10 \%$, and $>10 \%$ as low, medium and high, respectively (Table 2). The analyzed soil had a value of $0.20 \%$ total nitrogen which is a rating medium [27], who classified total nitrogen content of $<0.1,0.1-0.15,0.15-0.25$, and $>0.25$ as very low, low, medium, and high, respectively.

Moreover, the organic matter content of the soil $(3.92 \%)$ is medium according to the classification of Berhanu [28] where soils with organic matter content of $>5.20,2.6-5.2$, $0.8-2.6$ and $<0.8 \%$ were classified as high, medium, low and very low, respectively. The analysis indicated that the CEC of the soil was $17.86 \mathrm{cmol} \mathrm{kg}^{-1}$ (Table 2), which was medium, according to Landon [27], CEC by Ammonium Acetate at $\mathrm{pH}$ 7.0 method with values $<5,5-15,15-25,25-40$, and $>40$ are classified as very low, low, medium, high and very high. In general, the properties of the experimental soil and the weather conditions at the site were conducive for the growth of both maize and soybean.

Table 2. Major soil characteristics of the experimental site before planting.

\begin{tabular}{lll}
\hline Soil Character & Value & Status \\
\hline & Sand (\%) & 48 \\
Soil texture & Clay (\%) & 36 \\
& Silt (\%) & 16 \\
Soil textural class & & Sandy clay \\
Soil pH & 5.57 & Moderately acidic \\
Total nitrogen (\%) & 0.20 & Low \\
Organic Carbon (\%) & 2.27 & Medium \\
Organic matter (\%) & 3.92 & Medium \\
Cation Exchange Capacity $\left[\mathrm{cmol}(+) \mathrm{kg}^{-1}\right]$ & 17.86 & Medium \\
\hline
\end{tabular}

\subsection{Maize Components}

Maize phenology and growth parameters:

The main effect of variety and plant population of the intercropped soybean and their interaction showed no significant effect on days to $50 \%$ tasselling and silking of maize. On the other hand, the cropping system had a significant $(P<0.05)$ effect on days to $50 \%$ tasselling and silking of maize (Table 3 ). The absence of significant effects on the maize component could be due to the dominant nature of maize as compared to soybean in resource utilization. This is in agreement with Tilahun [29] report days to silking and tasseling of maize in maize/faba bean intercropping. Likewise, in maize and faba bean intercropping reported also no variation in days to silking and tasseling of maize [29]. Furthermore, day to $90 \%$ physiological maturity of maize was not significantly affected by main effect of soybean varieties. While the plant population of soybean and cropping 
system had a highly significant $(P<0.01)$ effect on days to $90 \%$ physiological maturity of maize (Table 3 ). Intercropped $75 \%$ of soybean with maize significantly delayed days to physiological maturity as compared to $25 \%$ of soybean (Table 3) may be due to competition effect of soybean plant population for nutrients especially water, which can result in lowered metabolic processes in the plant which increase maturity date. Teshome [30] reported days to $90 \%$ physiological maturity of maize was not significantly affected by the associated soybean varieties and the interaction of varieties by population.

Plant height of maize was not significantly affected by the main effects of soybean varieties, plant population of soybean, their interaction, and cropping system (Table 3). This was probably because of early sowing of maize helps to utilize important resources in maize-soybean varieties intercropping. The maize leaf area and leaf area index were highly significantly $(P<0.01)$ affected by plant population of soybean and cropping system (Table 3). The leaf area (LA) and leaf area index (LAI) of maize due to intercropping local variety $\left(3325 \mathrm{~cm}^{2}, 1.48\right)$ significantly higher than that of 'Boshe'. (3099 $\left.\mathrm{cm}^{2}, 1.38\right)$, respectively. And the $25 \%$ plant population of soybean population gave highest LA (3461.1 $\left.\mathrm{cm}^{2}\right)$ and LAI (1.54) while the lowest LA $\left(3046 \mathrm{~cm}^{2}\right)$ and LAI (1.35), was due to $75 \%$ plant population (Table 3 ) which might be due to increased competition for growth resources as the density of the associated soybean varieties increased.

This could be due to inter specific competition between associated crops for growth resources under the intercropping system than sole cropping. This result agreed with Tsubo et al. [31] who reported that on maize/bean intercropping, the intercropped maize leaf area was significantly reduced because of the photosynthetic organ (leaves) become thinner and reduced its area due to shading effect of the component crop. Wogayehu [32] also found that LAI of maize was significantly affected by intercropped bean varieties and Tilahun [29] reported that intercropping reduced LAI of maize in faba bean/ maize intercropping.

\section{Yield and Yield Components of Maize}

Ear length and Ear diameter: Soybean plant population and the interaction had a significant $(\mathrm{P}<0.05)$ effect on ear length and ear diameter of maize (Table 3). The highest ear length and ear diameter of maize were obtained from the intercropped soybean population of $25 \%(24.62 \mathrm{~cm}$ and $5.28 \mathrm{~cm})$ and $75 \%$ $(23.86 \mathrm{~cm}$ and $4.79 \mathrm{~cm})$, respectively. On the other hand, the lowest ear length and ear diameter of maize were obtained from the intercropped soybean population of $75 \%(23.86 \mathrm{~cm}$ and $4.79 \mathrm{~cm}$ ), respectively (Table 3 ). The highest ear length and ear diameter recorded from maize intercropped with soybean at $25 \%$ planting density might be due to less planting density that might have resulted in less competition. The lower ear length and ear diameter of maize recorded from $75 \%$ soybean intercropped with maize might be due to interspecific competition between component crops.

Number of Ears Per Plant: The main effects of the plant population showed a significant $(P<0.05)$ effect on the number of ears per plant (Table 3 ). The highest number of ears per plant (1.88) was obtained from maize intercropped with $25 \%$ of the soybean population while the lowest number of ears per plant (1.71) was obtained from maize intercropped with $75 \%$ of soybean population (Table 3). This might be due to increased interspecific competition for growth resources from the associated soybean as its density increased. Similarly, Teshome et al. [17] found that the number of an ear of maize was influenced by the main effects of plant population of soybean varieties and cropping system.

Table 3. The Phenology, Growth, and Yield and Yield related characters of maize as affected by the associated soybean varieties and planting densities grown in sole and intercropped with soybean at Hagalo area.

\begin{tabular}{|c|c|c|c|c|c|c|c|c|c|c|c|c|c|}
\hline Treatments & DT & DS & DM & $\begin{array}{l}\text { PH } \\
(\mathrm{cm})\end{array}$ & $\begin{array}{l}\text { LA } \\
\left(\mathrm{cm}^{2}\right)\end{array}$ & LAI & $\begin{array}{l}\text { EL } \\
(\mathrm{cm})\end{array}$ & $\begin{array}{l}\text { ED } \\
(\mathrm{cm})\end{array}$ & NEPP & HI (\%) & $\begin{array}{l}\text { HKW } \\
\text { (g) }\end{array}$ & $\begin{array}{l}\text { ADB } \\
\left(\text { tha }^{-1}\right)\end{array}$ & $\begin{array}{l}\text { GY } \\
\left(\text { tha }^{-1}\right)\end{array}$ \\
\hline \multicolumn{14}{|c|}{ Soybean varieties } \\
\hline Maize + Boshe & 74.62 & 78.22 & 136.49 & 222.80 & $3099^{c}$ & 1.38 & 24.15 & 5.06 & 1.81 & $38.38^{\mathrm{a}}$ & $26.33^{\mathrm{b}}$ & 18.64 & $7.15^{\mathrm{a}}$ \\
\hline Maize + Jalale & 74.47 & 78.15 & 136.48 & 220.89 & $3250^{\mathrm{b}}$ & 1.44 & 24.22 & 5.15 & 1.77 & $38.57^{\mathrm{a}}$ & $25.99^{\mathrm{a}}$ & 18.54 & $7.15^{\mathrm{a}}$ \\
\hline Maize +Local & 74.59 & 78.19 & 136.77 & 222.60 & $3325^{\mathrm{a}}$ & 1.48 & 24.22 & 4.99 & 1.73 & $37.41^{\mathrm{b}}$ & $26.0^{\mathrm{ab}}$ & 18.86 & $7.05^{b}$ \\
\hline LSD (0.05) & NS & NS & NS & NS & 137.1 & 0.061 & NS & NS & NS & 0.79 & 0.02 & NS & 0.03 \\
\hline \multicolumn{14}{|c|}{ Soybean population } \\
\hline Maize $+50 \%$ & 74.54 & 78.22 & $136.27^{\mathrm{b}}$ & 222.21 & $3168^{\mathrm{b}}$ & $1.41^{\mathrm{b}}$ & $24.12^{\mathrm{b}}$ & $5.14^{\mathrm{a}}$ & $1.72^{\mathrm{b}}$ & $38.15^{\mathrm{ab}}$ & $26.16^{\mathrm{b}}$ & 18.67 & $7.12^{\mathrm{b}}$ \\
\hline Maize $+75 \%$ & 74.57 & 78.18 & $137.97^{\mathrm{a}}$ & 221.65 & $3046^{c}$ & $1.35^{\mathrm{b}}$ & $23.86^{\mathrm{c}}$ & $4.79^{b}$ & $1.71^{\mathrm{b}}$ & $37.37^{\mathrm{b}}$ & $25.85^{\mathrm{c}}$ & 18.85 & $7.04^{c}$ \\
\hline $\operatorname{LSD}(0.05)$ & NS & NS & 0.336 & NS & 137.1 & 0.061 & 0.13 & 0.23 & 0.14 & 0.79 & 0.02 & NS & 0.03 \\
\hline CV (\%) & 0.3 & 0.20 & 0.20 & 0.98 & 4.3 & 4.3 & 0.56 & 4.46 & 8.09 & 2.07 & 0.42 & 2.76 & 0.51 \\
\hline \multicolumn{14}{|c|}{ Cropping System } \\
\hline Sole Cropping & $74.14^{\mathrm{b}}$ & $77.70^{\mathrm{b}}$ & $135.07^{\mathrm{b}}$ & 222.58 & $3329.3^{\mathrm{a}}$ & $1.48^{\mathrm{a}}$ & 25.27 & 5.52 & 1.89 & $40.44^{\mathrm{a}}$ & $26.35^{\mathrm{a}}$ & 18.98 & $7.43^{\mathrm{a}}$ \\
\hline Intercropping & $74.56^{\mathrm{a}}$ & $78.19^{\mathrm{a}}$ & $136.58^{\mathrm{a}}$ & 222.10 & $3173.6^{\mathrm{b}}$ & $1.41^{\mathrm{b}}$ & 24.20 & 5.07 & 1.77 & $38.7^{\mathrm{b}}$ & $26.01^{\mathrm{b}}$ & 18.65 & $7.19^{b}$ \\
\hline $\operatorname{LSD}(0.05)$ & 0.19 & 0.39 & 0.63 & NS & 116.17 & 0.04 & NS & NS & NS & 0.97 & 0.18 & NS & 0.21 \\
\hline
\end{tabular}

Means within the same column followed by the same letter or by no letters of each factor do not differ significantly at $5 \%$ probability level; LSD=Least Significant Difference $(P<0.05)$; CV=Coefficient of Variation; NS=Non Significant; DT=days to $50 \%$ tasseling; DS=days to $50 \%$ silking; DM=days to $90 \%$ maturity; $\mathrm{PH}=$ Plant height; $\mathrm{LA}=$ leaf area; $\mathrm{LAI}=$ leaf area index, $\mathrm{EL}=$ ear length; $\mathrm{ED}=$ ear diameter; $\mathrm{NEPP}=$ number of ears per plant; $\mathrm{HI}=$ harvest index; $\mathrm{HKW}=$ hundred kernel weight; $\mathrm{ADB}=$ above ground dry biomass; $\mathrm{GY}=$ grain yield;

Hundred Kernel Weight: The main effects of plant population, varieties of soybean and cropping system showed 
a significant $(\mathrm{P}<0.01)$ effect on a hundred kernel weight (Table 3$)$. The highest hundred kernel weight $(26.31 \mathrm{~g})$ was obtained from maize intercropped with $25 \%$ of the soybean population while intercropping with $75 \%$ soybean population gave the lowest hundred kernel weight (25.85 g) (Table 3). In conformity to this, significantly the highest hundred kernel weight $(26.33 \mathrm{~g})$ was recorded from 'Boshe' variety and the lowest hundred kernel weight $(25.99 \mathrm{~g})$ was obtained from 'Jalale' variety. Hundred kernel weight of maize was also significantly affected by the cropping system. A higher hundred kernel weight of maize $(26.35 \mathrm{~g})$ was obtained from sole maize and the lower hundred kernel weight of maize (26.01g) was obtained from the intercropped maize with soybean variety (Table 3 ).

Aboveground Dry Biomass: There were no significant effects of varieties, plant population of the intercropped soybean, and their interaction on aboveground dry biomass (Table 3). In conformity with this result, Teshome et al. [17] observed that the main effect of variety and plant population of the intercropped soybean and their interaction showed no significant effect on maize above-ground dry biomass. Similarly, Zerihun [33] reported no significant difference in dry biomass of the intercropped maize due to the associated soybean varieties and between the sole and intercropped maize for aboveground dry biomass, The decrease in the aboveground dry biomass of maize under intercropping might be due to competition between the two crops for growth resources. Another study reported by Behairy [34] and Kisetu and Nyasasi [35] confirmed that non-significant differences between monocropped maize and intercropped maize with soybean on aboveground dry biomass.

Harvest Index (HI) in $\%$ :The main effects of soybean varieties, plant population, and cropping system showed a significant $(\mathrm{P}<0.05)$ effect on harvest index while the interaction effect of soybean variety was not significant (Table 3 ). The highest harvest index of maize $(38.84 \%)$ was recorded from intercropping of maize with $25 \%$ of the soybean population whereas the lowest HI (38.15\%) was recorded from intercropping of maize with $50 \%$ of soybean population. Additionally, the highest HI (38.57\%) of the maize component was obtained in association with soybean variety 'Jalale' while the lowest HI (37.41\%) was obtained in association with soybean local variety (Table 3 ). In the other hand, significantly higher HI of maize (40.44\%) was obtained from sole maize than the intercropped maize $(38.7 \%)$ (Table 3). Lower HI of maize under intercropping might be due to interspecific competition for growth resources. The present result agreed with Zerihun [33] finding where higher HI $(44.7 \%)$ of maize was recorded from sole maize than intercropped maize (41.5\%) with soybean varieties.

Grain yield: The main effects of plant population, soybean varieties, and cropping system showed highly significant $(\mathrm{P}<$ 0.01 ) effects on grain yield of the maize component. However, grain yield was not significantly affected by their interactions (Table 3). The highest maize yield $\left(7.19 \mathrm{t} \mathrm{ha}^{-1}\right)$ was obtained from the combinations of $100 \%$ maize $\times 25 \%$ plant population of soybean 'Boshe' variety while the lowest grain yield $\left(7.04 \mathrm{t} \mathrm{ha}^{-1}\right)$ was obtained from a combination of $100 \%$ maize x $75 \%$ plant population of soybean. The highest grain yield of maize from $25 \%$ population of soybean variety 'Boshe' might be due to a reduction in competition for growth resources. Sole cropped maize had significantly higher grain yield $\left(7.43 \mathrm{tha}^{-1}\right)$ than the intercropped system $\left(7.19 \mathrm{t} \mathrm{ha}^{-1}\right)$ (Table 3$)$. The grain yield reduction of the intercropped maize might be associated with interspecific competition between the intercrop components for growth resources and the depressive effects of soybean on maize at the early growth stage because both crops were planted simultaneously and soybean has emerged earlier than maize. Following this result, Dechasa [36] reported that the yield of sole cropped sorghum was significantly higher than intercropped sorghum.

\subsection{Soybean Component}

\section{Growth Parameters}

Days to $50 \%$ flowering: The main effect of soybean varieties and plant population of soybean had a significant ( $\mathrm{P}$ $<0.01$ ) effect on days to $50 \%$ flowering (Table 4 ). This could be due to the varietal difference. On the other hand, local variety significantly delayed days to reach $50 \%$ flowering. Intercropped $25 \%$ of soybean with maize significantly delayed days to $50 \%$ flowering as compared to $50 \%$ and $75 \%$ of soybean (Table 4). This was probably due to relatively less competition between plants for growth resources, which allows the crop to more vegetative growth leading to delayed flowering. Similarly, Belstie et al. [37] reported that a prolonged period of flowering was observed for 1:1 spatial arrangement. Sole and intercropped soybean did not show significant effect. This result is in agreement with Njouku and Muoneke [38] who reported that there was no effect on cowpea intercropping on days to $50 \%$ as compared to the sole crop.

Days to $90 \%$ physiological Maturity: had significantly affected $(P<0.05)$ by the main effect of soybean varieties and plant population of soybean (Table 4 ). Intercropped $75 \%$ of soybean with maize significantly delayed days to physiological maturity of soybean as compared to $25 \%$ and $50 \%$ of soybean (Table 4) indicating competition effect of soybean plant population for nutrients especially water, which can result in lowered metabolic processes in the plant which increase maturity date. Moreover, maturity was significantly different among varieties of soybean. 'Jalale' and 'Boshe' reached days to $90 \%$ physiological maturity significantly earlier than intercropped local (Table 4).

Plant height: The main effect of soybean varieties and cropping system had a significant effect on plant height (Table 4). This may be due to the competition of plants for light. However, the height of soybean was not significantly affected by plant population of soybean. The highest height of soybean $(63.75 \mathrm{~cm})$ was recorded from intercropping of 'Jalale' with maize whereas the lowest height $(58.74 \mathrm{~cm})$ was recorded from intercropping of local variety with maize.

The number of primary branches The main effect of plant 
population, soybean varieties, and interaction of the main effects had a highly significant $(\mathrm{P}<0.01)$ effect on number of primary branches (Table 4$)$. The highest number of primary branches of soybean (5.90) was recorded from intercropping of 'Jalale' with maize whereas the lowest number of primary branches (2.98) was recorded from intercropping of local variety with maize. Soybean at $25 \%$ plant population and at $75 \%$ plant population gave significantly the highest (5.09) and lowest (3.10) primary branches, respectively (Table 4). These results agreed with that of Teshome [30] who reported that the highest number of primary branches was recorded from $25 \%$ soybean population while the lowest number of primary branches was recorded from $75 \%$ soybean population.

\section{Yield and Yield Components of Soybean}

The number of pods per plant: The number of pods per plant was highly significantly $(\mathrm{P} \quad 0.01)$ affected by the main effect of plant population, cropping system, interaction and soybean varieties (Table 4). The highest number of pods per plant (39.59) was recorded from $25 \%$ soybean population while the lowest number of pods per plant (34.46) was obtained from $75 \%$ soybean population (Table 4). The highest number of pods per plant (39.74) was obtained for variety 'Boshe' while variety local had the lowest (32.54) (Table 4). The decrease in the number of pods per plant at higher plant density might be due to increased inter and intraspecific competition for growth resources, which might have lead to a reduced number of effective branches. Similarly, Luiz and Robert [39] reported that increasing the bean population in maize/bean intercropping significantly decreased the number of pods per bean plant. A significantly higher number of pods per soybean plant (104.79) was obtained from intercropped than sole cropped soybean (36.96) (Table 4).

The number of seeds per pod: Number of seeds per pod was significantly affected $(\mathrm{P} \quad 0.05)$ by the main effect of the plant population of soybean and cropping system. However, the number of seeds per pod was significantly affected by plant population, interaction, and cropping system (Table 4).

Hundred Seed Weight: Hundred seed weight of the associated soybean was not significantly affected by the main effect of cropping system, but was significantly $(\mathrm{P}<0.01)$ affected by soybean variety, plant population, and interaction (Table 4). The highest hundred seed weight (20.21 g) was recorded for variety 'Jalale' while the lowest seed weight was recorded for variety Local (18.47 g) (Table 4). The variation in seed weight for varieties could be since seed size is a genetic trait hence it did not change much with a change in a cropping system. This result was in agreement with Zerihun [33] report that thousand seed weight of soybean was significantly $(\mathrm{P}<0.05)$ different under maize/soybean intercropping due to soybean variety.

Table 4. Phenology, Yield and Yield related, characters of soybean as affected by the associated soybean varieties and planting densities grown in the sole and intercropped with maize.

\begin{tabular}{|c|c|c|c|c|c|c|c|c|c|c|}
\hline Treatments & DF & DN & PH & NPB & NPPP & NSPP & HSW (g) & ADB $\left(\right.$ tha $\left.^{-1}\right)$ & HI (\%) & SY $\left(\right.$ tha $\left.^{-1}\right)$ \\
\hline \multicolumn{11}{|l|}{ Soybean varieties } \\
\hline Maize+Boshe & $68.16^{\mathrm{b}}$ & $111.49^{\mathrm{b}}$ & $63.75^{\mathrm{a}}$ & $5.90^{\mathrm{a}}$ & $42.58^{\mathrm{a}}$ & $2.80 \mathrm{a}$ & $18.66^{\mathrm{b}}$ & $5.15^{\mathrm{a}}$ & $31^{\mathrm{a}}$ & $1.58^{\mathrm{a}}$ \\
\hline Maize+Jalale & $67.14^{\mathrm{c}}$ & $111.26^{\mathrm{b}}$ & $60.25^{\mathrm{b}}$ & $3.32^{\mathrm{b}}$ & $40.74^{\mathrm{b}}$ & $2.77 \mathrm{~b}$ & $20.21^{\mathrm{a}}$ & $5.11^{\mathrm{a}}$ & $31 \mathrm{a}$ & $1.58^{\mathrm{a}}$ \\
\hline Maize+Local & $73.64^{\mathrm{a}}$ & $118.07^{\mathrm{a}}$ & $58.74^{\mathrm{c}}$ & $2.98^{\mathrm{c}}$ & $32.64^{\mathrm{c}}$ & $2.62 \mathrm{c}$ & $18.47^{\mathrm{b}}$ & $4.07^{b}$ & $22^{\mathrm{c}}$ & $0.91^{\mathrm{b}}$ \\
\hline $\operatorname{LSD}(0.05)$ & 0.078 & 0.266 & 0.267 & 0.32 & 0.32 & 0.15 & 0.32 & 0.04 & 0.002 & 0.01 \\
\hline \multicolumn{11}{|l|}{ Soybean densities } \\
\hline Maize $+25 \%$ & $69.73^{\mathrm{a}}$ & $113.45^{\mathrm{b}}$ & 60.91 & $5.09^{\mathrm{a}}$ & $40.06^{\mathrm{a}}$ & 2.94 & 18.85 & $4.67^{\mathrm{c}}$ & $27.78^{\mathrm{b}}$ & $1.31^{\mathrm{c}}$ \\
\hline Maize $+75 \%$ & $69.58^{\mathrm{b}}$ & $113.73^{\mathrm{a}}$ & 60.92 & $3.10^{\mathrm{c}}$ & $37.38^{\mathrm{c}}$ & 2.68 & 19.36 & $4.89^{\mathrm{a}}$ & $28.11^{\mathrm{ab}}$ & $1.39^{\mathrm{a}}$ \\
\hline LSD (0.05) & 0.078 & 0.266 & NS & 0.32 & 0.32 & NS & 0.32 & 0.04 & 0.004 & 0.01 \\
\hline CV $(\%)$ & 0.1 & 0.2 & 0.4 & 7.9 & 0.8 & 5.6 & 1.7 & 0.9 & 0.8 & 0.8 \\
\hline \multicolumn{11}{|l|}{ Cropping System } \\
\hline Sole Cropping & 68.24 & 113.52 & $56.65^{\mathrm{b}}$ & 4.81 & $104.79^{\mathrm{a}}$ & $2.98^{\mathrm{a}}$ & 20.02 & $8.19^{\mathrm{a}}$ & 25.70 & $2.22^{\mathrm{a}}$ \\
\hline Intercropping & 69.65 & 113.61 & $60.92^{\mathrm{a}}$ & 4.07 & $36.75^{\mathrm{b}}$ & $2.78^{\mathrm{b}}$ & 19.12 & $4.78^{\mathrm{b}}$ & 28.12 & $1.36^{\mathrm{b}}$ \\
\hline $\operatorname{LSD}(0.05)$ & NS & NS & 2.26 & NS & 14.34 & 0.04 & NS & 0.42 & 3.2 & 0.27 \\
\hline
\end{tabular}

Means in the same column followed by the same letters are not significantly different at $5 \%$ level of significance according to LSD test. NS=Not significant at $\mathrm{P}<0.05$; $\mathrm{LSD}=$ Least significant difference; $\mathrm{CV}=\mathrm{Coefficient}$ of variation, $\mathrm{DF}=$ days to flowering, $\mathrm{DM}=\mathrm{days}$ to maturity, $\mathrm{PH}=\mathrm{Plant}$ height; $\mathrm{NPB}=$ number of primary branch; NS=Non Significant; NPPP=number of pod per plant; NSPP=Number of seed per pod; $A D B=$ above ground dry biomass, HSW=Hundred seed weight; $\mathrm{SY}=$ Grain yield

Aboveground dry biomass of Soybean: The aboveground dry biomass of the soybean component showed a significant $(\mathrm{P}<0.01)$ variation between soybean varieties, plant population, and cropping system (Table 4). The highest aboveground dry biomass was obtained from $75 \%\left(5.12 \mathrm{t} \mathrm{ha}^{-1}\right)$ while the lowest biomass yield was from $25 \%\left(4.21 \mathrm{t} \mathrm{ha}^{-1}\right)$ soybean population (Table 4) and the highest aboveground dry biomass $\left(5.15 \mathrm{t} \mathrm{ha}^{-1}\right)$ was recorded from 'Boshe' variety of soybean followed by 'Jalale' variety $\left(5.11 \mathrm{t} \mathrm{ha}^{-1}\right)$. The cropping system also had a highly significant $(\mathrm{P}<0.01)$ effect on aboveground dry biomass of the soybean and maximum biomass yield $\left(8.19 \mathrm{t} \mathrm{ha}^{-1}\right)$ was recorded from sole cropped soybean than the intercropped soybean $\left(4.78 \mathrm{t} \mathrm{ha}^{-1}\right)$ (Table 4). The current finding was in line with Birteeb et al. [40] who reported that intercropping system significantly reduced the biomass yield of the intercropped legumes. The 
differences in canopy height of soybean varieties and maize lead to shading effect.

Harvest Index of Soybean: Harvest index of soybean was highly significant $(\mathrm{P}<0.01)$ affected by variety and plant population, their interaction, and cropping system (Table 4). The highest soybean harvest index $(28.33 \%)$ was obtained from $50 \%$ soybean population and the lowest soybean harvest index $(27.78 \%)$ was obtained from $25 \%$ population (Table 4). The highest harvest index was recorded from variety 'Boshe' and 'Jalale' intercropped with maize might be due to the high grain yield to biomass obtained by the variety as a result of high partitioning of dry matter to the grain.

Seed Yield of Soybean: There was also a significant $(\mathrm{P}<$ $0.01)$ variation in grain yield due to the effect of associated varieties, plant population, interaction, and cropping system (Table 4). The highest yield $\left(1.58 \mathrm{t} \mathrm{ha}^{-1}\right)$ was obtained from the intercropped variety 'Boshe' and 'Jalale' with maize (Table 4). This may be due to could be due to higher-yielding potential as it had the highest aboveground dry biomass and hundred grains weight. Similarly, Egbe [8] reported such significant yield differences among varieties of soybean in the intercropping system. With regards to plant population, the highest seed yield $\left(1.39 \mathrm{tha}^{-1}\right)$ was recorded from the soybean population of $75 \%$ followed by $50 \%$ soybean population $(1.38$ $\left.\mathrm{t} \mathrm{ha}^{-1}\right)$, and the lowest was obtained from $25 \%$ soybean population $\left(1.31 \mathrm{t} \mathrm{ha}^{-1}\right)$ (Table 4$)$.

Therefore, grain yield increased with the increase in plant population of soybean which could be the result of more plants established under the intercropping system. This conforms to Akunda [41] which demonstrated higher soybean populations provided a way to optimizing yields in soybean/millet intercropping systems. In the case of the cropping system, higher seed yield $\left(2.22 \mathrm{t} \mathrm{ha}^{-1}\right)$ was obtained from sole cropped soybean than the intercropped soybean $\left(1.36 \mathrm{t} \mathrm{ha}^{-1}\right)$ (Table 4). This reduction in soybean yields under intercropping could be due to interspecific competition between the intercrop components and also the aggressive effects of maize $\left(\mathrm{C}_{4}\right.$ species) on soybean, a $\mathrm{C}_{3}$ species. Also shading by the taller maize plants under the intercropping could reduce the photosynthetic rate of the lower growing plants and thereby reduce their yields. Muoneke et al. [42] reported similar yield reduction in soybean intercropped with maize and sorghum and attributed the yield depression to interspecific competition and the depressive effect of the cereals.

\subsection{System Productivity}

Land Equivalent Ratio (LER): The productivity of intercropping was evaluated using the partial and total LERs as indices. The partial LER of maize varied significantly in terms of soybean varieties and plant population. A significant increase in partial LER ( 0.44 to 0.70$)$ of soybean was calculated due to a proportional increase in planting densities (Table 5). In all intercrops, LER was superior in resources use efficiency as compared to sole cropping. This justified that the intercropping was better than their respective sole cropping. The intercropped maize yielded the equivalent of $58.18 \%$ to $68.57 \%$ and $41.4 \%$ to $60.76 \%$ of its sole crop yield in terms of soybean varieties and planting densities, respectively. Besides, soybean varieties yielded the equivalent of $31.43 \%$ to $41.82 \%$ of their sole crop yield, while $37.82 \%$ to $39.49 \%$ of their sole crop yield (Table 5) was obtained due to soybean planting densities. This showed that it was advantageous as compared to sole cropping of either of the component crops as depicted by total LER values above one indicated complementarity in resource utilization by the component crops.

Table 5. Main effects of Soybean varieties and their plant population on LER, GMV, and MAI of maize-soybean intercropping.

\begin{tabular}{|c|c|c|c|c|c|c|c|}
\hline \multirow{2}{*}{ Treatment } & \multicolumn{3}{|l|}{ LER } & \multicolumn{3}{|c|}{ Monetary value (Ethiopian Birr/ha) } & \multirow{2}{*}{$\begin{array}{l}\text { MAI (Monetary } \\
\text { advantage index) }\end{array}$} \\
\hline & Maize & soybean & Total & Maize & Soybean & GMV (Gross monetary value) & \\
\hline \multicolumn{8}{|c|}{ Soybean varieties } \\
\hline Maize+Boshe & $0.96^{\mathrm{a}}$ & $0.69^{\mathrm{a}}$ & 1.65 & $49406^{\mathrm{ab}}$ & $61567^{\mathrm{a}}$ & 110431 & $43716.64^{\mathrm{a}}$ \\
\hline Maize+Jalale & $0.95^{\mathrm{b}}$ & $0.68^{\mathrm{a}}$ & 1.63 & $48544^{\mathrm{b}}$ & $61228^{\mathrm{a}}$ & 109772 & $42427.21^{\mathrm{b}}$ \\
\hline Maize+Local & $0.96^{\mathrm{a}}$ & $0.44^{\mathrm{b}}$ & 1.4 & $48864^{\mathrm{a}}$ & $56721^{\mathrm{b}}$ & 105585 & $30167.14^{\mathrm{c}}$ \\
\hline $\operatorname{LSD}(0.05)$ & 0.004 & 0.008 & & 696.9 & 703.2 & & 391.94 \\
\hline \multicolumn{8}{|c|}{ Soybean population } \\
\hline Maize+25\% & $0.97 \mathrm{a}$ & $0.59^{\mathrm{c}}$ & 1.56 & $49893^{\mathrm{a}}$ & $60391^{\mathrm{c}}$ & 110284 & $39589.13^{\mathrm{a}}$ \\
\hline Maize $+50 \%$ & $0.96 \mathrm{~b}$ & $0.62^{\mathrm{a}}$ & 1.58 & $49801^{\mathrm{a}}$ & $60841^{\mathrm{b}}$ & 110642 & $40615.42^{\mathrm{b}}$ \\
\hline Maize+75\% & $0.95 \mathrm{c}$ & $0.62^{\mathrm{a}}$ & 1.57 & $47121^{\mathrm{b}}$ & $58285^{\mathrm{a}}$ & 105406 & $38268.42^{\mathrm{c}}$ \\
\hline $\operatorname{LSD}(0.05)$ & 0.004 & 0.008 & & 696.9 & 703.2 & & 391.94 \\
\hline CV $(\%)$ & 0.4 & 1.3 & & 1.4 & 1.2 & & 1.8 \\
\hline \multicolumn{8}{|c|}{ Cropping System } \\
\hline Sole Cropping & $1^{\mathrm{a}}$ & $1^{\mathrm{a}}$ & 1:00 & 48937.9 & $58649^{\mathrm{b}}$ & 107586.9 & - \\
\hline Intercropping & $0.97^{\mathrm{b}}$ & $0.61^{\mathrm{b}}$ & 1.58 & 49905 & $61924^{\mathrm{a}}$ & 111829 & 43428 \\
\hline LSD (0.05) & 0.01 & 0.1 & 0.11 & NS & 727.96 & & 593.30 \\
\hline CV (\%) & 0.42 & 12.3 & 12.4 & 17.3 & 4.56 & & 1.44 \\
\hline
\end{tabular}

Means within the column and rows followed by the same letter do not differ significantly at $5 \%$ probability level; LSD=Least Significant Difference; $\mathrm{CV}=$ Coefficient of Variation, ETB=Ethiopian Birr $=1$ US dollar $=\sim 33$ Birr $)$.

Gross Monetary Value (GMV): The result revealed that the GMV increased with the increase in planting density of soybean in intercropped maize/soybean. This might be because of higher seed yield values and the higher price per $\mathrm{kg}$ of soybean which contributed more in gross monetary value than maize as depicted by the monetary value of soybean varieties in intercrops. Thus, the highest GMV of ETB (Ethiopian Birr) 49893.00 ha $^{-1}$ and lowest GMV of ETB 
47121.00 per ha were obtained when maize intercropped with soybean at planting densities of $25 \%$ and $75 \%$, respectively (Table 5). This depicted that the GMV of intercrops (ETB $49905.00 \mathrm{ha}^{-1}$ ) was higher than that of sole cropped maize (ETB $48937.90 \mathrm{ha}^{-1}$ ) (Table 5). Thus, the intercrop system was economically feasible relative to sole crop maize as reported from different intercrop studies including Segun Olasanmi and Bamire [43] (maize-cowpea), Addo-Quaye et al. [44] (maize-soybean), and Alemayehu et al. [45] (maize common bean). However, the GMV (ETB $58649.00 \mathrm{ha}^{-1}$ ) of sole cropped soybean was by far superior to GMV of intercrops (ETB $61924.00 \mathrm{ha}^{-1}$ ) which showed that the GMV of sole cropped soybean was greater than that of intercrops by ETB 967.10 ha $^{-1}$ Table 5). This might be because of a higher contribution of soybean seed yield from sole cropping compared to intercrop as the higher price per $\mathrm{kg}$ of soybean.

Monetary Advantage Index: Monetary advantage (MA) of intercropping was used to calculate the absolute value of the yield advantage. According to Willey [24] the appropriate economic assessment of intercropping should be in terms of increased value per unit area of land.

Economic Analysis of Intercropping: Economic analysis revealed that the highest net benefit $44491.4 \mathrm{ETB} \mathrm{ha}^{-1}$ was obtained from maize intercropped with 'Boshe' variety at population of $50 \%$ and the net benefit of intercrops higher than that of sole crops (Table 6).

Therefore, intercrop system was economically feasible relative to sole crop maize.

Table 6. Economic analysis of maize-soybean intercropping system.

\begin{tabular}{|c|c|c|c|c|}
\hline Treatments & Adjusted yield $\left(\mathrm{kg} \mathrm{ha}^{-1}\right)$ & TVC (ETB ha-1) & Total revenue $\left(\right.$ ETB ha $\left.{ }^{-1}\right)$ & Net benefit (ETB ha-1) \\
\hline $\mathrm{M}+25 \%$ Boshe & 8777.88 & 6440.65 & 49986 & 43545.35 \\
\hline $\mathrm{M}+50 \%$ Boshe & 8807.4 & 6530.60 & 51022 & 44491.4 \\
\hline $\mathrm{M}+75 \%$ Boshe & 8807.22 & 6620.30 & 49968 & 43347.7 \\
\hline $\mathrm{M}+25 \%$ Jalale & 8649 & 6440.50 & 49248 & 42807.5 \\
\hline $\mathrm{M}+50 \%$ Jalale & 8777.16 & 6530.85 & 49770 & 43239.15 \\
\hline $\mathrm{M}+75 \%$ Jalale & 8744.22 & 6620.45 & 49590 & 42969.55 \\
\hline$M+25 \%$ Local & 7857.54 & 6440.30 & 45540 & 39099.7 \\
\hline $\mathrm{M}+50 \%$ Local & 7791.48 & 6530.40 & 45126 & 38595.6 \\
\hline $\mathrm{M}+25 \%$ Local & 7762.42 & 6620.85 & 44934 & 38313.15 \\
\hline Sole Maize & 6732 & 5150.80 & 40392 & 35241.2 \\
\hline Sole Boshe & 3436.2 & 3394.05 & 16560 & 13165.95 \\
\hline Sole Jalale & 3361.5 & 3394.10 & 16200 & 12805.9 \\
\hline Sole Local & 3047.76 & 3394.20 & 14688 & 11293.8 \\
\hline
\end{tabular}

$\mathrm{TVC}=$ Total variable cost; Total variable cost included labor cost $\left(\mathrm{ETB} 80.0\right.$ man-day $\left.{ }^{-1}\right)$, fertilizers cost $\left(\mathrm{NPS}=1554.07 \mathrm{ETB} \mathrm{kg}^{-1}, \mathrm{Urea}=1411.19 \mathrm{ETB} \mathrm{kg}^{-1}\right)$ and soybean seed cost $\left(10.0 \mathrm{ETB} \mathrm{kg}^{-1}\right)$

\section{Conclusion}

The present study demonstrated that the main effect of soybean varieties, population and cropping system significantly $(\mathrm{p}<0.01)$ affected growth, yield and yield components of maize. Higher grain yield was recorded in sole crop maize. Cropping system significantly affected grain yield where the higher grain yield was recorded in sole crop maze. Maize inter cropping with soybean varieties at $75 \%$ plant population reduced maize yield. And, the highest grain yield was recorded in association with Boshe and Jalale varieties of soybean. Furthermore, the study showed intercropping has advantage compared to sole cropping as the LER values were greater than 1 . Thus, relatively high LER was obtained at intercropping of $100 \%$ maize with $25 \%$ Boshe variety. However, the highest MAI (43716.64) and the highest net benefit (44491.4 $\mathrm{ETB} \mathrm{ha}^{-1}$ ) were obtained from intercropping of maize with Boshe at $50 \%$ of its sole population. Generally, the result revealed that intercropping of Boshe with maize at $50 \%$ of its sole seed rate was superior and can be recommended for local farmers production.

\section{Acknowledgements}

We thank the Oromia Public Service for their financial support and Oromia Agricultural and Natural Resource Office for the administration services rendered during study period.

\section{References}

[1] Birhan A, Sofiya H, Temesgen D, Kassu T, Mihreteab H. (2016). Soil Fertility Management Studies on Wheat In Ethiopia: A Review. Ethiopian Journal of Natural Resources, 16: $1-2$.

[2] Farooq M, Bajwa AA, C Sardar A,. Zahid CA (2013). Application of Allelopathy in Crop Production. International Journal of Agriculture \& Biology.

[3] Lulie B (2017). Intercropping Practice as an Alternative Pathway for Sustainable Agriculture: A review. Acad. Res. J. Agri. Sci. Res. 5 (6): 440-452.

[4] Lithourgidis A S, Dordas CA. Damalas CA, Vlachostergios DN (2011). Annual intercrops: an alternative pathway for sustainable agriculture. Journal of Crop Sciences, 5 (4): 396410. 
[5] Waddington S R., Mulugetta M, Siziba S, Karigwindi J (2007). Long-term yield sustainability and financial returns from grain legume-maize intercrops on a sandy soil in sub humid north central Zimbabwe. Expl Agric. Vol. 43, pp. 489-503.

[6] Tamiru H (2014). Effect of Intercrop row arrangement on maize and haricot bean productivity and the residual soil. World Journal of Agricultural Sciences, 2 (4): 069-077.

[7] Brooker, R. W, A. E. Bennett, W. Feng -Cong, T. J. Daniell, T. S. Georgem, P. D. Hallett, et al. (2015. Improving intercropping: A synthesis of research in agronomy, plant physiology and ecology. New Phytologist. 206, 107-117.

[8] Egbe O, Alibo S, Nwueze I (2010). Evaluation of some extraearly-and early maturing cowpea varieties for intercropping with maize in southern guinea Savanah of Nigeria. Agriculture and Biology Journal of North America, 1 (5): 845-858.

[9] Fathi N O (2014). Crop yield and nitrogen bio availability mediated by nitrogen fertilization in maize/soybean intercropping system with and without Rhizobium Inoculation. Alexandria Science Exchange Journal, 35 (2).

[10] Seran T H, Brintha I (2010). Review on maize based intercropping. Journal of Agronomy, 9 (3): 135-145.

[11] Beedy T L, Snapp S, Akinnifesi F K, Sileshi G W (2010). Impact of Gliricidia sepium intercropping system. Agricultural Ecosystem and Environment, 138 (3/4), 139- 146.

[12] Teshome G, Tamado T, Negash G (2016). Influence of Varieties and Population of Intercropped Soybean with Maize on Land Equivalent Ratio (LER) and Growth Monetary Value (GMV) of the Component Crops. Journal of Biology, Agriculture and Healthcare, Vol. 6, No. 11. www.iiste.org.

[13] FAO (Food and Agricultural Organization) (2017). Data-base agricultural production (FAO). http://faostat.fao.org/. Accessed on September 30, 2019.

[14] Berhanu A, Adam B, Yalew M (2018). Analysis of Cost and Return of Soybean Production Under Small Holder Farmers in Pawe District North Western Ethiopia. Journal of Natural Sciences Research, Vol. 8, No. 1, 2018. Accessed on July 12, 2019.

[15] Seran T H, Brintha I. (2009). Studies on determining a suitable pattern of capsicum (Capsicum annum L.)-vegetable cowpea (Vigna unguiculata L.) intercropping. Karnataka Journal of Agricultural Science, 22: 1153-1154.

[16] Padhi A K, Panigrahi R K, Jena B K (2010). Effect of planting geometry and duration of intercrops on performance of pigeonpea-finger millet intercropping systems. Indian J. Agric. Res. 44, 43-47.

[17] Teshome G, Tamado T, Negash G (2015). Effect of Varieties and Population of Intercropped Soybean with Maize on Yield and Yield components at Haro Sabu, Western Ethiopia. Science, Technology and Arts Research Journal, 4 (4): 31-39.

[18] MOANR (Ministry of Agriculture and Natural Resource) (2016). Plant Variety Release, Protection and seed Quality Directorate: Crop Varieties Register Addis Ababa, Ethiopia. Issue No. 19

[19] Tadesse J, Leta T, Techale B, Lemi B (2018). Genetic variability, heritability and genetic advance of maize (Zea mays L.) inbred lines for yield and yield related traits in southwestern Ethiopia. Journal of Plant Breeding and Crop Science, Vol. 10 (10), pp. 281-289.

[20] Sticker F C, Wearden S, Pauli A W (1961). Leaf Area Determination in Grain Sorghum. Agronomy Journal, 53: 187-188.

[21] Eyasu E, Shanka D, Dalga D, Elias E (2018). Yield Response of Maize (Zea mays L.) Varieties to Row Spacing Under Irrigation at Geleko, Ofa Woreda, Wolaita Zone, Southern Ethiopia. Journal of Experimental Agriculture International 20 (1): $1-10$.

[22] Kibiru K (2018). Effect of Inter Row Spacing on Yield Components and Yield of Soybean [Glycine Max (L.) Merrill] Varieties in Dale Sedi District, Western Ethiopia. Agri Res\& Tech: Open Access J. 18 (4).

[23] Mead R, Willey R W (1980). The concept of a land equivalent ratio and advantages. Experimental Agriculture, 16: 217- 226.

[24] Willey RW (1979). Intercropping - its importance and research needs. Field Crops Research 32: 1-10.

[25] Gomez K. A, Gomez A A (1984). Statistical Procedures for Agricultural Research. 2nd Edition. John Wiley and Sons Inc. Inter-Science Publications. New York. pp. 180-225.

[26] Onwume I C, Sinha I D (1991). Field crop production in tropical Africa: Principles and Practice. Technical Center for Agricultural and Rural Cooperation, Netherlands. https://books.google. com.et.

[27] Landon J R (1991). Brooker Tropical Soil Manual: A hand book for soil survey and Agricultural land evaluation in the tropics and Subtropics. Longman scientific and technical, Essex, Newyork, p. 474.

[28] Berhanu D (1980). The physical criteria and their rating proposed for land evaluation in the highland region of Ethiopia. Land use planning and regulatory department, Ministry of Agriculture. Addis Ababa, Ethiopia.

[29] Tilahun $\mathrm{T}$ (2002). Effects of Planting Arrangement of Component Crops on Productivity of Maize/Faba Bean Intercropping Systems. MSc. Thesis, Haramaya, University, Ethiopia.

[30] Teshome G (2017). Performances of Different Varieties and Population of Soybean (Glycine max L.) under Intercropping Systems with Maize (Zea mays L.). Advances in Life Science and Technology, Vol. 53: 2224-7181. www.iiste.org.

[31] Tsubo M, Walker S, Ogindio H O (2005). A simulation model a cereal-legume intercropping for semi- arid regions. Model applications. Field Crop Res. 93: 23-33.

[32] Wogayehu W (2005). Evaluation of common bean (Phaseolus vulgaris L.) varieties intercropping with maize (Zea mays L.) for double cropping at Haramaya and Hirna Areas, Eastern Ethiopia. MSc. Thesis, Haramaya University, Ethiopia.

[33] Zerihun A (2011). System Productivity as Influenced by Integrated Organic and Inorganic Fertilizer Application in Maize (zea mays 1.) Intercropped with Soybean (Glycine max L. Merrill) Varieties at Bako, Western Ethiopia. M. Sc. Thesis. Haramaya University, Ethiopia.

[34] Behairy TG (1994). Effect of intercropping patterns on soybean growth and photosynthetic apparatus. Egyptian Journal of Physiological Sciences, pp: 167-178. 
[35] Kisetu E, Nyasasi B T (2014). Determination of land productivity under maize-cowpea intercropping system in agro ecological zone of mount Uluguru in Morogoro, Tanzania. Global Journal of Agricultural Sciences Vol. 2: 147-157.

[36] Dechasa H (2005). Effect of moisture conservation methods and plant density of component crops on performance of sorghum/bean intercropping in Meiso district, west Hararghe. M. Sc. Thesis, Haramaya University, Ethiopia.

[37] Belstie L, Walelign W, Sheleme B (2016). Determinations of haricot bean (Phaseolus vulgaris L.) planting density and spatial arrangement for staggered Intercropping with Maize (Zea mays L.) at Wondo Genet, Southern Ethiopia. Academic Research Journal, 4 (6): 297-320.

[38] Njouku D N, Muoneke C O (2008). Effect of cowpea planting density on growth, yield and productivity of component crops in cowpea/cassava intercropping system. Journal of Tropical Agriculture, Food, Environment and extension, 72 (2): 106113.

[39] Luiz B M, Robert W W (2003). Effects of plant population and nitrogen fertilizer on yield and efficiency of maize-bean intercropping. Pesq agropec bras Brasília 38 (11): 1257-1264.

[40] Birteeb P T, Addah W, Jakper N, Addo-Kwafo A (2011). Effects of intercropping cereal-legume on biomass and grain yield in the savannah zone. Livestock Research for Rural Development, 23 (198).
[41] Akunda E M (2001). Intercropping and population density effects on yield component, seed quality and photosynthesis of sorghum and soybean. Journal of Food Technology (Africa) 6: 170-172.

[42] Muoneke C O, Ogwuche M O, Kalu B A (2007). Effect of maize planting Density on the performance of maize/soybean intercropping system in a guinea savanna agroecosystem. Afrcan Journal of Agricultural Research 2: 667-677.

[43] Segun-Olasanmi A O, Bamire A S (2010). Analysis of costs and returns to maize-cowpea intercrop production in Oyo state, Nigeria, September 19-23, 2010, Poster presented at the Joint 3rd African Association of Agricultural Economists (AAAE) and 48thAgricultural Economists Association of South Africa (AEASA) Conference. Cape Town, South Africa.

[44] Addo-Quaye A, Darkwa A, Ocloo G K (2011). Yield and productivity of component crops in a maize-soybean intercropping system as affected by time of planting and spatial arrangement. Journal of Agriculture and Biological Science, 6 (9): 50-57.

[45] Alemayehu A, Tamado T, Nigusie D, Yigzaw D, Tesfaye T, Wortmann C S (2016). Maize-common bean/lupine intercrop productivity and profitability in maize-based cropping system of Northwestern Ethiopia. Ethiop. J. Sci. \& Technol. 9 (2) 6985 . 